\title{
Elizabeth J. Perry, Challenging the Mandate of Heaven. Social Protest and State Power in China
}

New York, London, M.E. Sharpe, 2001, 376 p.

Jean-Louis Rocca

\section{OpenEdition}

\section{Journals}

Édition électronique

URL : http://journals.openedition.org/chinaperspectives/829

DOI : 10.4000/chinaperspectives.829

ISSN : 1996-4617

\section{Éditeur}

Centre d'étude français sur la Chine contemporaine

Édition imprimée

Date de publication : 1 mai 2004

ISSN : 2070-3449

\section{Référence électronique}

Jean-Louis Rocca, « Elizabeth J. Perry, Challenging the Mandate of Heaven. Social Protest and State

Power in China », China Perspectives [En ligne], 53 | May- June 2004, mis en ligne le 24 avril 2007, consulté le 21 décembre 2020. URL : http://journals.openedition.org/chinaperspectives/829 ; DOI : https://doi.org/10.4000/chinaperspectives.829

Ce document a été généré automatiquement le 21 décembre 2020.

(c) All rights reserved 


\title{
Elizabeth J. Perry, Challenging the Mandate of Heaven. Social Protest and State Power in China
}

New York, London, M.E. Sharpe, 2001, 376 p.

\author{
Jean-Louis Rocca
}

1 This book is in reality a collection of articles and contributions that have been published previously and partially rewritten by the author. An introduction is intended to bring some coherence to the whole. The chapters address various facets of "social protest" (violence between peasant communities, anti-tax revolts, worker agitation) in different historical contexts (the end of the Qing dynasty, the republican era, the socialist period and post-Mao China). A complete panorama is thus offered to the reader of the way in which social groups have expressed their point of view and defended their interests over one-and-a-half centuries.

2 At the historiographic level, the contributions are all of a very good quality. The historical context is sharply presented, the actors and the actions depicted with precision. "Predators and Protectors: Strategies of Peasant Survival 1845-1945" describes the modes of organisation that the peasants deployed to defend themselves or, the other side of the coin, to capture the resources of others. "Protective Rebellion: Tax Protest in Late Qing China" highlights how the leading citizens used the peasant militia to launch anti-tax movements in the face of a state considered predator. "Heterodox Rebellion? The Mystery of Yellow Cliff" emphasises the importance of charismatic leaders in messianic revolts. "Predatory Rebellion: Bai Lang and Social Banditry" depicts the tight relationships that existed between a "bandit" such as Bai Lang and Sun Yat-sen's entourage, thus putting forward certain affinities between crime and politics, and the social aspect (or at least the discourse) in which banditry dresses itself up in China.

3 "Skilled Workers and the Chinese Revolution: Strikes Among Shanghai Silk Weavers, 1927-1937" and "Labor Divided: Sources of State Formation in Modern China" deal with the nature of the first Chinese proletariat and its forms of protest. The two chapters 
describe a group driven by very deep fractures based on the origin and the levels of technical competence. One thus perceives the increasing role played by these fractures in the political aggregation of the disaffections, with the nationalists asserting themselves among the lower strata and the communists doing likewise among the working aristocracy. In "Contradictions under Socialism: Shanghai's Strike Wave of 1957", the author takes up the analysis in terms of the fragmentation of the working class in order to describe the demonstrations of 1956-1957. The divergence of interests and representation among different categories of workers prevents the protest from developing into a general movement.

4 Complementing this emphasis on fragmentation, "Working at Cross-Purposes: Shanghai Labor in the Cultural Revolution" applies different frameworks of analysis to the political positions defended by three groups of workers: to the partisans of the "revolution" a "psycho-cultural" grid; to the "conservatives" a grid defined in terms of network; and finally, to the factions demanding better living conditions (economicism) a grid centred on interest group theory. "Rural Violence in a Socialist China" is devoted to an analysis both of inter-community violence and peasant protest.

Elizabeth Perry puts great store by continuity, in particular the importance of religious references and traditional social structures (family, lineage) which remain the basis for any collective action. Of course, public policies constitute the events that trigger protest, but the general impression is that of a systematic return to the representations and to the old methods of organisation. Finally, "Casting a Chinese 'Democracy' Movement: Legacies of Social Fragmentation" returns to a fairly widespread conception of the failure of the democracy movement: by trying to find allies among the bureaucracy rather than among other social groups, the students sealed their fate.

Unfortunately, if the book has plenty to offer on the two levels of description and context, the absence of a solid theoretical framework leaves the reader with a sense of frustration. This is not a unique case. A number of American works lack any genuine theoretical elaboration. One is often left with historiographic, ethnographic ${ }^{1}$ or bluntly ideological considerations. ${ }^{2}$ It seems that the problem resides in a certain distrust of, even a certain contempt for, conceptualisation in general and an astonishing disregard for the theoretical contributions made by European research in the social sciencesalthough of course these are not always available in English! The basis is then provided by "cobbling together" some "concept tools" that supposedly represent the process of modernisation-the necessity of an autonomisation of society in relation to the state, modern protest as the fruit of an alliance between different social groups, democratisation as the conquest of the middle class, the importance of culture, etc.without the validity of these concepts being justified in any way.

7 Elizabeth Perry's book does not escape these bad habits. We thus learn here that China is an authoritarian state, but without knowing exactly what that means and especially without any consideration being given to the "historical variations" of the regime. From the 1950s to the 1980s, and passing through the Cultural Revolution, what meaning are we to give to "authoritarianism"? Similarly, with the nature of the state in part determining the conditions of protest against it, it should be necessary to compare and contrast the concept with that of "totalitarianism" (Arendt). More generally, it is surprising not to find here a reflection on power (Foucault, Elias). For the post-Maoist period, we are left with a very classic conception: the "rupture" between state and 
society and the strict opposition of "dominators" and "dominated". Yet recent works reveal the complexity of the relations between the two sides of the gulf3.

As is customary, James Scott and Charles Tilly are mobilised as referees, but in an imprecise manner. For example, in Scott, the notion of the moral economy cannot be reduced to questions of subsistence. It would, moreover, have been useful to refer in this field to the father of this idea (E.P. Thompson), who provides the foundation for Scottian analysis. ${ }^{4}$

9 Finally, and this is the principal criticism that can be made of this book, the author systematically gives priority to the old in relation to the new, to continuity in relation to rupture. Implicitly or explicitly, culturalism emerges as the intellectual reference by default in the majority of the chapters: explicitly through the references to political culture, to democratic political culture or to a certain "tradition" of protest that has been prevalent through the ages; ${ }^{5}$ implicitly by the recourse to surprising historical short cuts. For example, the "rebel" Zhang Jizhong is judged to be close to Li Hongzhi, the leader of the Falun Gong-but are not the differences between these two personalities more interesting and more significant? Mao and Mencius are both supposed to have encouraged revolt-to rebel is justified. However, numerous European authors have put an end to the myth of this "transcendent" conception of tradition. Tradition is invented, manipulated, indigenised, and whatever the circumstances it cannot lay claim to any a priori determination of behaviour. Of course, it is not a question here of denying history, but, quite the contrary, of understanding how that history is tangibly reinterpreted by the actors, and thus of avoiding tautological judgements.

\section{NOTES}

1. See for example the book by Dorothy Solinger, Contesting Citizenship in Urban China. Peasant Migrants, the State and the Logic of Market, Berkeley, University of California Press, 1999, a work that features a wealth of information but is almost entirely devoid of any conceptual approach.

2. I am thinking for example of the debates on "civil society" or "democratisation".

3. See for example the works of Isabelle Thireau.

4. Edward P. Thompson, "The Moral Economy of the English Crowd in the Eighteenth Century", Past and Present, No. 51, May 1971, pp. 76-136.

5. Paul Veyne, Les Grecs ont-ils cru à leurs mythes? Essai sur l'imagination constituante, Paris, Le Seuil, 1983; Jean-François Bayart, L'Illusion identitaire, Paris, Fayard, 1996; Eric J. Hobsbawm and Terence Ranger (eds.), The Invention of Tradition, Cambridge, Cambridge University Press, 1996. 